\title{
ASSOCIATION BETWEEN CHRONIC ENERGY DEFICIENCY AND ANEMIA IN PREGNANT WOMEN IN LHOKSEUMAWE, ACEH
}

\author{
Helliyana, Evawany Y. Aritonang, Rahayu Sanusi
}

Masters Program in Public Health, Universitas Sumatera Utara

\begin{abstract}
Background: Chronic energy deficiency is the most widespread nutritional deficiency affecting half the world's children. There is much concern about the situation and considerable efforts are being made to alleviate this state of affairs. This study aimed to determine the association between chronic energy deficiency and anemia in pregnant women in Lhokseumawe, Aceh.

Subjects and Method: This was a cross-sectional study conducted at Puskesmas (Community Health Center) Muara I, Lhokseumawe, Aceh. A total of 90 pregnant mothers were selected for this study. The dependent variable was anemia. The independent variable was chronic energy deficiency. Data on anemia were taken from the medical record. Chronic energy deficiency was measured by questionnaire. The data were analyzed by a simple logistic regression.

Results: Chronic energy deficiency is associated with an increased risk of anemia in pregnant mothers $(\mathrm{OR}=13.82 ; 95 \% \mathrm{CI}=4.74$ to $40.32 ; \mathrm{p}<0.001)$.

Conclusion: Chronic energy deficiency increases the risk of anemia in pregnant mothers.
\end{abstract}

Keywords: chronic energy deficiency, anemia, pregnant mother.

\section{Correspondence:}

Helliyana. Masters Program in Public Health, Universitas Sumatera Utara, Jl. Prof. T. Maas, Medan, North Sumatera. Email: andybaso11@gmail.com.

Mobile: 085260129999. 